\title{
https://doi.org/10.30853/filnauki.2020.10.26
}

\section{Рядовых Наталья Александровна}

\section{Метафорическое осмысление святости в жанре акафиста}

Цель исследования - изучить способы метафорического осмысления понятия "святой" в жанре акафиста. В статье на материале текстов акафистов, посвященных православным святым, рассматриваются особенности экспликации абстрактного понятия "святой" с помощью метафор конкретных предметов и явлений. Научная новизна заключается в том, что впервые предпринимается попытка осмысления понятия "святой" с помощью метафор, используемых в акафистах. В результате исследования выделяются группы когнитивных метафор, которые отражают своеобразие религиозно-нравственного сознания и восприятия материального мира и представляют многомерный символический эквивалент понятия "святой".

Адрес статьи: www.gramota.net/materials/2/2020/10/26.html

\section{Источник}

Филологические науки. Вопросы теории и практики

Тамбов: Грамота, 2020. Том 13. Выпуск 10. С. 135-140. ISSN 1997-2911.

Адрес журнала: www.gramota.net/editions/2.html

Содержание данного номера журнала: www.gramota.net/materials/2/2020/10/

\section{(c) Издательство "Грамота"}

Информация о возможности публикации статей в журнале размещена на Интернет сайте издательства: www.gramota.net Вопросы, связанные с публикациями научных материалов, редакция просит направлять на адрес: phil@gramota.net 
10. Национальный корпус русского языка [Электронный ресурс]. URL: http://www.ruscorpora.ru (дата обращения: 03.01.2020).

11. Панов М. В. О слове как единице языка // Ученые записки Московского городского педагогического института им. В. Л. Потемкина. 1956. Т. 51. Вып. 5. С. 162-174.

12. Петеленкова М. Г. Конфликт этимологического и денотативного значения: дисс. ... к. филол. н. М., 2004.327 с.

13. Реформатский А. А. Введение в языковедение. М.: Аспект Пресс, 2000. 537 с.

14. Русская грамматика: в 2-х т. / гл. ред. Н. Ю. Шведова. М.: Наука, 1980. Т. 1.783 с.

15. Савицкий В. М. Специфика лексических идиом // Самарский научный вестник. 2013. № 1 (2). С. 38-40.

16. Словарь русской идиоматики [Электронный ресурс] / под ред. Г. И. Кустовой. URL: https://gufo.me/dict/idiomatic/ (дата обращения: 12.08.2020).

17. Современный толковый словарь русского языка [Электронный ресурс] / под ред. Т. Ф. Ефремовой. URL: https://dic.academic.ru/contents.nsf/efremova (дата обращения: 15.06.2020).

18. Толковый словарь русского языка [Электронный ресурс] / под ред. Д. Н. Ушакова. URL: https://dic.academic.ru/ contents.nsf/ushakov/ (дата обращения: 11.08.2020).

19. Фёдоров А. И. Фразеологический словарь русского литературного языка [Электронный ресурс]. URL: https://phraseology. academic.ru/ (дата обращения: 12.08.2020).

\title{
Structural-Semantic Features of Composite Idiom and Phraseological Unit: Similarities and Differences
}

\author{
Merkur'eva Nataliya Mikhailovna, $P h D$ \\ Plekhanov Russian University of Economics, Moscow \\ merkureva.natalia51@mail.ru
}

\begin{abstract}
The research objectives are as follows: to identify typical features of idiomatic compound words, to justify the status of composites as systemic units of the Russian phraseological system. The author provides a comparative analysis of semantically equivalent composites and phrasal idioms. Scientific originality of the paper involves the comprehensive approach to studying lexical idioms, which includes lexicological, lexicographical and functional aspects. The conducted research allows concluding that structural-semantic features of semantically equivalent composites and phrasal idioms coincide: composites and phraseological units contain the same set of bound morphs, which makes it possible to generate new semantic meanings. It is proved that composites and phraseological units equally possess the idiomaticity feature, which serves as an additional argument to consider idiomatic compound words as systemic units - "composite idioms".
\end{abstract}

Key words and phrases: composite idiom; compound word; lexical idiom; phrasal idiom; phraseological unit; idiomatic meaning; idiomaticity of derivative word.

Цель исследования - изучить способы метафорического осмысления понятия «святой» в жанре акафиста. В статье на материале текстов акафистов, посвященных православным святым, рассматриваются особенности экспликации абстрактного понятия «святой» с помощьью метафор конкретных предметов и явлений. Научная новизна заключается в том, что впервые предпринимается попытка осмысления понятия "святой» с помощью метафор, используемых в акафистах. В результате исследования выделяются группы когнитивных метафор, которые отражают своеобразие религиозно-нравственного сознания и восприятия материального мира и представляют многомерный символический эквивалент понятия «святой».

Ключевые слова и фразы: религиозный функциональный стиль; жанр; акафист; когнитивная метафора; святой.

Рядовых Наталья Александровна

Уральский федеральный университет имени первого Президента России Б. Н. Ельичин, г. Екатеринбург 2013071@mail.ru

\section{Метафорическое осмысление святости в жанре акафиста}

Актуальность темы обусловлена недостаточной изученностью акафиста в функциональной стилистике. Это связано с тем, что религиозный стиль, к которому относится жанр акафиста, становится объектом научных изысканий относительно недавно - на рубеже XX-XXI вв. В настоящее время существуют описания общей специфики религиозного стиля, активно изучаются функционально-стилистические особенности отдельных жанров. По замечанию В. В. Одинцова, каждый жанр определенного стиля характеризуется «единством конструктивного принципа», а также «своеобразием используемых стилистических фигур» [17, с. 156]. Конструктивный принцип религиозного стиля соотносится с религиозным сознанием, в основе которого лежат идеи двоемирия и стремления к спасению $[11$, с. 18], и может формулироваться как «абсолютизм в границах иерархичной дихотомичности Божественного и земного» [15, с. 208], а также, по мнению Т. В. Ицкович, рассматривается как «прототекстуальность», то есть «преемственность способов текстуальной обработки выдвигаемых концептов мировоззрения» [12, с. 11]. 
Действием конструктивного принципа обосновывается такая стилевая черта религиозного стиля, как «символизация сакрального мира и духовного состояния человека» [13, с. 415]. Данная функциональностилистическая особенность обусловливает использование в религиозных текстах когнитивных метафор, функциональной особенностью которых является способность превращаться «из средств создания образов... в способ формирования недостающих языку значений» [5, с. 336], иными словами, «думать об одной области... через призму другой (из области-источника в область-мишень)» [20, с. 352].

С помощью когнитивных метафор может раскрываться вся семантическая полнота многомерного абстрактного понятия. Проблема заключается в отсутствии систематизированных метафорических описаний отвлеченных понятий в религиозных текстах, в частности, связанных с представлением о святости в жанре акафиста. В статье предпринимается попытка обобщения метафорических возможностей выражения данного понятия.

В процессе исследования решаются следующие задачи: во-первых, охарактеризовать специфику жанра акафиста; во-вторых, выявить и описать возможности метафорического выражения понятия «святой» в обозначенных текстах; в-третьих, обосновать классификацию выявленных метафор.

Материалом исследования послужили тексты акафистов православным святым. Изучено 150 текстов [1-4].

В работе применяются методы сплошной выборки, таксономического описания, а также приемы лингвокультурологического анализа.

В качестве теоретической базы используются работы, посвященные изучению специфики когнитивных метафор, таких ученых, как Н. Д. Арутюнова, В. З. Демьянков, Ф. А. Елоева, Е. В. Перехвальская, Э. Саусверде, Е. А. Ермолин, А. А. Кибрик, И. М. Кобозева, И. А. Секерина, Т. В. Юрьева, Р. В. Гиббс [5; 8-10; 20-22], рассматриваются описания религиозного функционального стиля, представленные в трудах Т. В. Ицкович, М. Н. Кожиной, Л. Р. Дускаевой, В. А. Салимовского, Н. А. Купиной, Т. В. Матвеевой [11-13; 15], используются научные исследования жанра акафиста таких авторов, как М. Е. Козлов, Ф. Б. Людоговский, А. В. Попов $[14 ; 16 ; 18]$.

Практическая значимость исследования заключается в том, что выявляемая в статье особенность текстов акафистов, связанная с продуцированием определенных типов когнитивных метафор, может быть использована как иллюстрация функционально-стилистических особенностей религиозного стиля на практических занятиях курса «Стилистика современного русского языка».

Акафист - это «церковное хвалебное песнопение, чин молитв, прославляющих Иисуса Христа, Богородицу, того или иного святого, Крест Господень, церковный праздник» [19, с. 26]. Изучение акафистов многопланово. Известны описания акафистов с богословской точки зрения (К. В. Воробьев; И. А. Гарднер; Д. В. Гордеев; И. П. Давыдов; свящ. М. Козлов; свящ. Киприан (Керн); свящ. К. Никольский; Г. Папайанис; свящ. М. Плякин); существуют искусствоведческие работы по акафисту (И. В. Самсонова). Как особый жанр акафист рассматривается в литературоведении (Б. П. Иванюк; А. А. Чуркин) и становится объектом научных изысканий в лингвистике (С. С. Аванесов; Т. С. Борисова; А. А. Камалова; А. А. Красильникова; О. А. Шапорева и др.). Наиболее значимый вклад в современные лингвистические исследования акафиста вносится Ф. Б. Людоговским [16]. В настоящее время в лингвистике остаются недостаточно исследованными функционально-стилистические особенности акафиста.

Первый фундаментальный труд, посвященный описанию акафистов, появляется в самом начале XX века. Профессор Казанского университета А. В. Попов составляет комплексную характеристику всех известных к тому времени акафистов [18]. Исследователь церковной гимнографии обращает внимание на метафоричность акафистов, которая обусловлена тем, что «церковному певцу... <необходимо> ... духовное выразить в конкретном, материальном образе так, чтобы этот телесный образ не ограничивал духовного, не заслонял его собой, чтобы рельефно обнаружив духовное... сам он отпал бы, как шелуха, чтобы потерялись из виду отчетливые черты его телесности и физической ограниченности» [Там же, с. 585].

Идеи А. В. Попова перекликаются с результатами исследований в области когнитивной метафоры, полученными в XXI веке. Современные ученые, наблюдая за «уровнем метафоричности» различных языков, приходят к выводу о том, что использование метафор в языке связано с «необходимостью говорить на абстрактные темы». Необходимость «говорить на абстрактные темы» (или отсутствие таковой необходимости) представляется дифференциальным признаком определенного функционального стиля [9, с. 82]. Соответственно, религиозный функциональный стиль, экстралингвистическим фактором которого является религиозное сознание, оперирующее абстрактными понятиями, предполагает высокий уровень метафоричности. Жанр религиозного стиля - акафист отражает данную специфику.

Акафист формируется как многократное подражание энкомиастическому гимну Пресвятой Богородице, в котором с помощью «символов сокровенного смысла» [21, с. 18] выражается глорификация, то есть похвала. Акафист сохраняет специфику протожанра молитвы, в котором «интенция хвалы» рассматривается «на лингвостилистической основе» как один из особых «прагматических компонентов» [12, с. 12].

В течение нескольких столетий гимнографический текст первого акафиста остается уникальным и сохраняет неповторимое название «Акафист» (что в переводе означает «неседальная песнь», то есть песнь, которая исполняется стоя). Впоследствии, в процессе активного текстотворчества, формируется корпус текстов акафистов, авторы которых расширяют круг глорифицируемых адресатов. Текст-первоисточник получает более развернутое (конкретизирующее) именование - «Акафист ко Пресвятой Богородице». Указание на святость Богородицы, фиксируемое в названии акафиста, воспринимается как свойство из области духовного мира, которое становится объектом глорификации в тексте.

В толково-энциклопедическом словаре «Лексика современного русского православия», составленном Г. Н. Скляревской, лексема «святой» обозначается как «исходящий от Бога, связанный с Богом, близкий 
к Богу» и как «наделенный божественной благодатью, являющийся источником божественной силы» [19, с. 477]. Абстрактность духовного понятия «святой» находит конкретные метафорические воплощения - «метафорические репрезентации» [22, р. 147] в акафисте-первотексте. Описание системы метафорического своеобразия первичного текста «Акафиста» не является предметом рассмотрения данной работы. Однако неутраченная связь с первоисточником подразумевает сохранение определенной специфики и прослеживается в последующих текстах.

Обратимся к результатам анализа материала. В текстах акафистов используется метафорическое осмысление святого человека через реалии из мира живой природы. Святой - адресат акафиста - сравнивается с птицами: птице, парящая в небеса [3, с. 618]; горлица пустыннолюбная [4, с. 328]; кокош, птенцы своя охраняюший [3, с. 22], а также - с растениями: благовозделанная лозо винограда [4, с. 125]; древо, насажденное посреде Церкве Божия [Там же]; маслино, елей милости Божия источивщая [Там же, с. 62]. В текстах акафистов употребляется метафора пчелы: пчело трудолюбивая, мудре взыскавщая ияветы, в них же мед истины и спасения [2, с. 759]; пчело, дыма идольского отлетевщая [3, с. 395].

Метафора птицы имеет в христианстве особое символическое значение, которое кодируется в текстах Священного Писания. В Ветхом Завете метафорическое наименование птицы передает идею жертвенности «чистые птицы» приносятся в жертву. Птица может восприниматься как символ возвращения, в том числе возвращения человека в Небесное Отечество - к Богу-Отцу [6, с. 143]. Метафора птицы, собирающей своих птенцов, связывается с действиями Иисуса Христа. В Евангелии от Матфея приводятся слова Спасителя: «Иерусалиме, Иерусалиме... колькрать восхотех собрати чада твоя, якоже собирает кокош птениь своя, и вы не восхотесте» (Мф. 23:37). С помощью метафоры птицы в текстах акафистов выстраивается параллель со святыми намерениями Сына Божиего. Таким образом, использование прецедентных, в том числе прототекстуальных, метафор становится средством узнаваемого символического осмысления святости.

Генезис некоторых растительных метафор связан с текстом первого «Акафиста ко Пресвятой Богородице». Ср.: древо светлоплодовитое; древо благосеннолиственное [1, с. 8]. Прототекстуальная метафора виноградной лозы фиксируется в Евангелии от Иоанна. Иносказательно говорит о себе Иисус Христос: «Aз есмь лоза истинная, и Отеи мой делатель есть» (Ин. 15:1).

Многозначной является метафора пчелы. Различны когнитивные основания для выстраивания метафорического переноса при формировании понятия «святой» с помощью данного христианского символа. Это и преследование врагов, свойственное пчелам (Втор. 1:44); и трудолюбие, и мудрость, и благодарное почитание людьми (Притч. 6:8).

Нам представляется уместным предположить, что метафоры объектов мира живой природы можно рассматривать также на основании общей семантической принадлежности к лексеме «живой». В словарной статье «Толкового словаря русского языка» В. И. Даля дефиниция лексемы «живой» соотносится с тем, «кто жив, кто живет, живущий, в ком или в чем есть жизнь; о Боге: сый, сущий, всевечный, в самостоятельном бытии пребывающий; о человеке и животном: дышащий... сохраняющий признаки земной жизни; о душе: одаренный духовною, бесплотною жизнию, или же... спасенный» [7, с. 323]. Примечательно, что первую позицию в толковании занимает семантико-атрибутивная связь с Богом, которая расширяется коррелятами - «человек и животное», «душа», «растение». Когнитивное замещение абстрактного понятия «святой» конкретными объектами живой природы строится на имплицитной связи святого человека с «сущим», «всевечным» [Там же] - живым Богом.

В текстах акафистов используются метафоры из мира неживой природы. В этих метафорах, равным образом как и в группе метафор живой природы, прослеживается действие конструктивного принципа религиозного стиля, эксплицирующего «иерархическую дихотомию Божественного и земного» [15, с. 208] и преемственную связь с прототекстом [12, с. 10]. Ввиду обширности материала описание этимологии каждого вида метафор из мира неживой природы не представляется возможным. Перечислим некоторые метафорические репрезентации данной группы, выборочно сопровождая комментарием отдельные примеры иносказательного описания.

Так, в акафистах святым встречаются метафоры, связанные с осмыслением сущности «начала». Упоминается начало дня: утро, добродетельми облагоуханное [3, с. 158]; заре безсмертия [4, с. 76]. Называется начало нового (после зимнего периода) природного цикла: весно, лучами благодати осиянная [3, с. 158]. С помощью метафор начала выстраивается аллюзия на Евангельское Откровение, в котором Господь говорит о себе: «Аз есмь альфа и омега, начаток и конеи» (Откр. 1:8). Божественное свойство «начала» проецируется на сущность святого человека.

Выделяется подгруппа метафор, называющих явления природы: громе, беззаконно живущая устрашаяй [Там же, с. 191]; молние, гордыню низложивиая [Там же, с. 146]; облацы, источаюшии росу учений [2, с. 8]; роса благодатная, орошающчая и веселящая наша сердия [3, с. 52]. Отметим, что метафоры «грома» и «молнии» используются в первичном «Акафисте ко Пресвятой Богородице» (ср.: молние, души просвещаюющая; яко гром враги устрашающзая [1, с. 12]).

Выявляется подгруппа метафор природного мира, связанная с метафорами небесных тел: новое светило хладного севера [4, с. 171]; солнце лежавших во зле [3, с. 627]; звездо, чудесно возсиявшая в Сибирстей стране [4, с. 848]; луно совершенная [3, с. 394].

Метафоры объектов мира неживой природы включают метафоры земли: земле благая, семя Слова Божия восприявшая [Там же, с. 24]; нива благовозделанная к плодоносию духовному [Там же, с. 63]; метафоры воды: многоцелебныя кладязю неисчерпаемый [4, с. 462]; щедрот и милования струе неизсякаемая [Там же, с. 76]; 
реко исиелений благодатных [Там же, с. 119]; метафоры огня: пламя благочестия [Там же, с. 144]; огонь богодухновенных вещзаний [3, с. 18]; пламеновидный столпе [Там же, с. 81].

В качестве примера прототекстуальной репрезентации понятия «святой» прокомментируем употребление метафоры огня. В данной подгруппе выборочно сохраняется символическая специфика первичного «Акафиста ко Пресвятой Богородице» (ср.: огненный столпе, наставляющий сущия во тьме [1, с. 8]), а также поддерживается прототекстуальная преемственность с текстом Священного Писания, в котором упоминается «столп огненный» (Исх.: 13:21-22), в виде которого Бог сопровождает народ израильский при Исходе из египетского плена. Подобная прототекстуальная преемственность наблюдается в метафорах воды источниче, в жизнь вечную текий [3, с. 160] (ср.: «Отвеща Иисус и рече ей: “...но вода, юже (Аз) дам ему, будет в нем источник воды, текущия в живот вечный”» (Ин. 4:14)).

В текстах акафистов используются метафоры веществ земной коры (камня, минерала, металла) в качестве обозначения таких свойств, как твердость, уверенность, надежность, внутренняя красота, значимость, ценность: каменю надежды жизни [4, с. 85]; крепкаго терпения адаманте [3, с. 487]; злато, во все концы блещзание о себе испущзаюее [Там же, с. 30]; сребро, от скверн греховных очищенное [Там же].

Метафоры из мира неживой природы рассматриваются как частные проявления «предзнаний» $[8$, с. 5] о той или иной стороне понятия святости. За каждым образом окружающего мира закрепляется семантически дифференциальный признак, который соотносится с внутренним состоянием или поступками святого человека. Нередко в составе метафоры нерукотворного объекта или явления присутствует адъективный указатель, обладающий конвергирующими (зачастую - аксиологическими) характеристиками роса благодатная [3, с. 52], земле благая [Там же, с. 24]; адамант драгоценный [4, с. 752].

Метафора из мира живой и неживой природы может рассматриваться как «явление бытийного абсолюта бесконечного - в конечном и чувственном образе», которая «появляется, чтобы открыть земле небо, миру дольнему - мир Горний» [10, с. 4]. В текстах акафистов обозначенная «чувственность» образа усиливается метафорами, построенными на особенностях чувственной перцепции окружающего мира.

Зрительное восприятие представлено «световыми» метафорами: светильниче света небесного [4, с. 492]; древния России сияние [Там же, с. 44]; свещц многосветлая в земли Российстей, просвещающая всякого человека [Там же, с. 84]. Метафора света является прототекстуальной, трансцендентное значение которой объясняется в Священном Писании: «Свет истинный, Иже просвещает всякого человека грядущаго в мир» (Ин. 1:9) это сам Бог (отметим, что текст первичного «Акафиста ко Пресвятой Богородице» содержит метафору светоприемной свещи, сущим во тьме явльшейся, где под свещзй понимается Богородица, а метафора света обозначает Сына Божиего [1, с. 12]).

В качестве «световых» метафор могут рассматриваться и метафоры огня, используемые также в группе метафор из мира неживой природы: огнем ревности по Бозе горяй [3, с. 170]. Метафоры огня можно отнести и к группе метафор тактильного восприятия: пламенем гнева Господня враги веры опаляй [Там же, с. 168]. В группе метафор тактильного ощущения для передачи состояния святости, как правило, применяются определения, включающие сему «тепла»: теплейший любителю Господа Иисуса [2, с. 682]; теплый пред Господем о нас молитвенниче [3, с. 512].

Среди метафор, корреспондирующих с органами перцепции, можно выделить «звуковые» метафоры, которые раскрывают понятие «святой», используя возможность слухового восприятия мира. В качестве «звуковых» метафор применяются звучащие музыкальные инструменты: свиреле доброгласная, песньми духовными веселящая души человеков [4, с. 161]; труба духа, воспевшая глас истинного богословия [3, с. 397]; кимвале, всех на славословие Божие созываяй [Там же, с. 30]. Также используются метафоры звучащего голоса человека: девственного жития сладкогласный услаждателю [Там же, с. 144] или поющей птицы ластовице сладкопесенная [4, с. 491].

В текстах акафистов святым встречаются метафоры, отражающие обонятельные особенности восприятия, которые эксплицируются через описание особого аромата и его источника: молитв благоприятное кадило [Там же, с. 890]; молитвы фимиам благовонный [4, с. 148]; земли отечества твоего иввете благоуханный [3, с. 587].

Метафоры, символично преображающие вкусовое восприятие, представлены двумя видами. Встречаются автономные метафоры, базирующиеся на осязательных ассоциациях: сладкое вино, в точиле Иисусовом изгнетенное [4, с. 31]; жаждущих вечной жизни сладкое питие [Там же, с. 173]. Также присутствуют комплексные метафоры, синхронно сочетающие ассоциации, построенные на осязательном и слуховом восприятии мира: орган псалмопения сладкостройный [Там же, с. 148]; свирель сладкозвучная [2, с. 749].

Специфика представленной группы метафор связана с употреблением устойчивого эпитета «сладкий», за которым в форме суперлатива закрепляется именование Сына Божиего - Иисусе Сладчайший [Там же, с. 3]. Метафора сладость святая [1, с. 8] используется для обозначения Иисуса Христа в первичном тексте «Акафиста ко Пресвятой Богородице». Тип когнитивной метафоры, основанный на осязательном восприятии мира, иносказательно образует латентную связь святого человека с Богом и Богородицей.

Акафисты святым Божиим угодникам содержат метафоры, основанные на общественно значимых видах человеческой деятельности. Частотной является метафора воина, защитника: воин противу князя власти воздушныл [3, с. 142]; православия страже неусыпающий [Там же, с. 350]; дивньй ратоборче, все оружия Божия восприемыцй [4, с. 181]. Святой человек воспринимается как тот, кто может спасти, защитить. Метафора победоносной воительницы взбранной Воеводе победительная [1, с. 3] в составе конструкции обращения 
к Божией Матери является началом текста первичного «Акафиста ко Пресвятой Богородице» и распознается как имманентный атрибут святости.

Назовем примеры других видов деятельности, включенных в метафорическую ткань акафистов в качестве обозначения понятия «святой»:

- метафора руководствующего начала: вождю, ищущиих спасения [4, с. 86]; верный путеводитель ко спасению [3, с. 331]; верный руководителю шествующих ко Господу [Там же, с. 45]; на корабли кормчий [Там же, с. 163];

- метафора садовника, сеятеля: сеятелю мудрый благочестия [Там же, с. 476]; духа благочестия насадителю [Там же, с. 191]; благий делателю винограда Христова [Там же, с. 25];

- метафора целителя: врач скорый всем земным [Там же, с. 268]; безмездно паче естества врачу скоромилостивый [4, с. 470]; немощных врач [3, с. 452].

Авторы акафистов, метафорически описывая деятельность святого человека, обозначают те виды работ, которые называются в Евангелии в связи с земной жизнью Христа (ср.: «И приступиша к нему народи мнози, имущее с собою хромыя, слепья, немыя, бедныя, и ины многи: и привергоша их к ногама Иисусовыма, и исцели их» (Мф. 15:30)) или с упоминанием подобного рода деятельности в притчах Христа (ср.: «Человек некий бе домовит, иже насади виноград...» (Мф. 21:33-42)).

Эксплицитное обозначение святости представляет собой группа метафор, основанная на прецедентности имен собственных. Имена (чаще всего) ветхозаветных святых воспринимаются как атрибуция святости: Авелю, кровию Христовой окропленный [Там же, с. 34]; новый Иов [4, с. 146]; Авраам, послушания ради Гласу Божию, отечество твое Нижний Новград, обитель и знаемых оставивый [Там же, с. 158].

Имплицитным сигналом связи с Горним миром, на которой основывается осмысление святости, являются аллюзии на цитаты Евангелия: чистых сердцем смиренный учителю [Там же, с. 173] (ср.: «Блажени чистии сердцем: яко тии Бога узрят» (Мф. 5:8)); мзду многу на небесех стяжавый [3, с. 284] (ср.: «Радуйтеся и веселитеся, яко мзда ваша многа на небесех» (Мф. 5:12)); соле земли [4, с. 772] (ср.: «Bы есте соль земли» (Мф. 5:13)).

Опора на Евангелие как прототекст [12, с. 11] демонстрирует экспликацию конструктивного принципа религиозного стиля. Прототекстуальность когнитивных метафор в текстах акафистов представляется каналом когнитивно-иносказательной связи трансцендентного и земного.

Еще одна группа метафор применяется в качестве осмысления святости. Это метафоры из мира материальных предметов - изделий: святыя иконы Богоматере колеснице [4, с. 175]; стено нерушимая посреде бури страстей языческих [2, с. 758]; чаше всезлатая, черплющая обилие дарований от Дароподателя Христа [3, с. 47]; сосуды веры, надежды и любви [Там же, с. 771]; лествице, возводящая богомудрых иноков [Там же, с. 45]; отверстая врата [Там же, с. 162]; ключу молитвы [Там же, с. 247]; ците ве$p b l$ [Там же, с. 252]. Некоторые из метафор этой группы используются в первичном тексте «Акафиста ко Пресвятой Богородице» (ср.: стена еси девам, Богородице Дево [1, с. 11]; чаше, черпающая радость [Там же, с. 12]; лествице небесная [Там же, с. 4]; ключу Царствия Христова [Там же, с. 9]). Метафорические именования Пресвятой Богородицы проецируются на святых - адресатов акафистов, обнаруживая через номинативную связь с Богородицей экспликацию понятия «святой».

Изначальная сакральность предмета, используемого в качестве метафоры святости, выступает в качестве усиливающего когнитивного дополнения - священный предмет связывается в сознании с Богом так же, как связан с Богом святой человек: одушевленныя скрижали закона Господня [4, с. 69]; олтарь, на освященное служение Господу освященный [3, с. 143]; живый свитче закона Божия [Там же, с. 61].

Таким образом, мы приходим к следующим выводам. Анализ текстов показывает, что акафист как жанр религиозного стиля характеризуется высоким уровнем метафоричности. Метафора, в составе которой используется обозначение материального предмета или явления, выступает в качестве средства переосмысления сложного понятия духовного мира. Применение метафор в акафистах обусловлено спецификой религиозного сознания, являющегося экстралингвистическим фактором религиозного функционального стиля. Отвлеченность религиозных понятий обосновывает многообразие метафорических репрезентаций в религиозных текстах. Классификация групп когнитивных метафор, обозначающих абстрактное понятие «святой», раскрывает особенность когнитивных подходов. Описание святости становится возможным через осмысление предметов (и явлений) символов из мира живой и неживой природы, а также - через раскрытие особенностей перцептивного познания. Большое значение имеет теологическая подготовленность человека, воспринимающего метафорические коды, знание Священного Писания (прототекста), в котором закладываются основные ключи христианской символики, а также знание текста-первоисточника - «Акафиста ко Пресвятой Богородице».

Результаты проведенного исследования подтверждают функционально-стилистическую обоснованность высокой метафоричности анализируемых текстов. Изучение возможности метафорического осмысления важных концептуальных понятий духовного мира в текстах акафистов представляется перспективным.

\section{Список источников}

1. Акафист ко Пресвятой Богородице // Акафистник: в 4-х т. Мн.: Харвест, 2007. Т. 1. С. 3-15.

2. Акафистник: в 4-х т. Мн.: Харвест, 2007. Т. 2. 815 с.

3. Акафистник: в 4-х т. Мн.: Харвест, 2007. Т. 3. 831 с.

4. Акафистник: в 4-х т. Мн.: Харвест, 2007. Т. 4.943 с.

5. Арутюнова Н. Д. Функциональные типы языковой метафоры // Известия АН СССР. Серия «Литература и языкознание». 1978. Т. 37. № 4. С. 333-343. 
6. Архимандрит Никифор. Библейская энциклопедия. М.: Терра, 1991. 904 с.

7. Даль В. И. Толковый словарь русского языка. М.: Эксмо, 2012. 896 с.

8. Демьянков В. 3. Когниция и понимание текста // Вопросы когнитивной лингвистики. 2005. № 3 (4). С. 5-10.

9. Елоева Ф. А., Перехвальская Е. В., Саусверде Э. Метафора и эвристическая функция языка (бывает ли язык без метафор) // Вопросы языкознания. 2014. № 1. С. 78-99.

10. Ермолин Е. А. Символы русской культуры X-XVIII вв. Ярославль: Изд-во ЯГПУ им. К. Д. Ушинского, 1998.116 с.

11. Ицкович Т. В. Категориально-текстовая специфика современной православной проповеди. Екатеринбург: Ажур, 2015. $150 \mathrm{c}$.

12. Ицкович Т. В. Прототекстуальность как конструктивный принцип религиозного стиля // Вестник Волгоградского государственного университета. Серия 2. Языкознание. 2018. Т. 17. № 1. С. 6-16.

13. Кожина М. Н., Дускаева Л. Р., Салимовский В. А. Стилистика русского языка: учебник. М.: Флинта; Наука, 2018. 464 с.

14. Козлов М. Е. Акафист в истории православной гимнографии // Журнал Московской Патриархии. 2000. № 6. С. 83-88.

15. Купина Н. А., Матвеева Т. В. Стилистика современного русского языка: учебник для академического бакалавриата. М.: Юрайт, 2017. 415 с.

16. Людоговский Ф. Б. Структура и поэтика церковнославянских акафистов. М.: Ин-т славяноведения РАН, 2015. 352 с.

17. Одинцов В. В. Стилистика текста. М.: Наука, 1980. 263 с.

18. Попов А. В. Православные русские акафисты. М.: Изд-во Московской Патриархии Русской православной церкви, 2013. $656 \mathrm{c}$.

19. Скляревская Г. Н. Лексика современного русского православия: толково-энциклопедический словарь. СПб.: Контраст, 2016. $688 \mathrm{c.}$

20. Фундаментальные направления современной американской лингвистики / под ред. А. А. Кибрика, И. М. Кобозевой, И. А. Секериной. М.: Изд-во МГУ, 1997. 453 с.

21. Юрьева Т. В. Православная картина мира: мировосприятие и художественный образ: курс лекций. Ярославль: Изд-во ЯГПУ им. К. Д. Ушинского, 2006. 170 с.

22. Gibbs R. W. The Cambridge handbook of metaphor and thought. Cambridge, 2008. 537 p.

\title{
Metaphorical Interpretation of Sainthood in Akathist Hymns
}

\author{
Ryadovykh Natalya Alexandrovna \\ Ural Federal University named after the first President of Russia B. N. Yeltsin, Yekaterinburg \\ 2013071@mail.ru
}

The paper examines the means of the "saint" concept metaphorical interpretation in Akathist hymns. By the material of Akathist hymns to Orthodox saints, the author analyses specificity of the "saint" concept explication through metaphorical representation of concrete objects and phenomena. Scientific originality of the study lies in the fact that the concept "saint" is for the first time considered through the prism of metaphors used in Akathist hymns. The research findings are as follows: the author identifies a set of cognitive metaphors that represent specificity of religious and moral consciousness and worldview and serve as a multidimensional symbolic equivalent of the "saint" concept.

Key words and phrases: religious functional style; genre; Akathist hymn; cognitive metaphor; saint.

https://doi.org/10.30853/filnauki.2020.10.27

Дата поступления рукописи: 07.08.2020

Статья посвящена морфологическому и семантическому анализу существительньх адъективного типа склонения - субстантиватов, использующихся в наименованиях предприятий питания и торговли. Цель исследования - доказать продуктивность модели и обосновать идею социокультурной референции субстантиватов в наименовании предприятий торговли и питания современного дискурса в сопоставлении с результатами более ранних исследований. В основе научного исследования - базовые теоретические положения ученыхлингвистов XX в., а также новые изыскания, предпринятые современныли исследователями. Научная новизна заключается в описании семантических и морфологических особенностей окказиональных и потенциальных субстантиватов, использованных в нейминге на данном этапе развития языка. В результате изучения актуального языкового материала сделан вывод о том, что изучаемые лексемы потенциальны и содержат значение национально-культурного компонента, характеризуя динамику развития языковой системы.

Ключевые слова и фразы: субстантивация; номинация; потенциальное слово; окказионализм; лингвокультурология.

Фысина Ульяна Николаевна, к. филол. н.

Российский государственный университет правосудия, г. Москва

unfysina@gmail.com

\section{От столовой к «Кудяблишной»: субстантиваты в нейминге предприятий торговли и питания в современном русском языке}

На современном этапе функционирования русского языка можно отметить активное использование слов адъективного типа склонения для наименования лица, брендов, предприятий питания и торговли. В статье 